\title{
MICROPLASTIC IN MARINE ENVIRONMENT AND ITS IMPACT
}

\author{
Yudha Gusti Wibowo ${ }^{1 *}$, Anis Tatik Maryani ${ }^{1}$,Dewi Rosanti ${ }^{2 *}$, Desy Rosarina ${ }^{3}$ \\ *e-mail: yudhagustiwibowo26@gmail.com,dwrosanti@gmail.com \\ ${ }^{1}$ Postgraduate Program, Universitas Jambi, Indonesia \\ ${ }^{2}$ Departement of Science, Universitas PGRI Palembang Indonesia \\ ${ }^{3}$ Department of Engineering, Universitas Muhammadiyah Tangerang, Indonesia
}

\begin{abstract}
This article was the result of a research of literature study sources and impact of microplastic in the marine environment. Plastic debris could make microplasric caused by ultraviolet and give some negative impact for marine environment. Plastic debris in marine environment has come from industrial and fishing activities (human activities). All of marine environment in the world has contaminated by microplastic, microplastic will give negative impact for marine biota, recent study inform that turtle and fish have high microplastic content in both them. plastics industries should take responsibility for the end-of-life oftheir products by introducing plastic recycling or upgrading programmers.
\end{abstract}

Keywords: Microplastic, marine environment, environment, plastic debris, plastics

\section{INTRODUCTION}

Environment has been degradation caused by industrial activities (Winarno et al., 2019; Wibowo \& Syarifuddin, 2018; Rosanti, 2015; Wibowo \& Sadikin, 2019; Rosanti, 2016; Wibowo et al., 2018). Environmental damage has attracted much attention from both of researchers and general public, plastic waste is therefore hazardous for the environment. Plastics are lightweight, synthetic or semi-synthetic organic polymers that are cheap, strong, corrosion-resistant and durable (Derraik, 2002; Wick et al., 2013), nobody knows how much time plastic waste to completely degrade in the marine environment. Many types of plastics in marine environment such as fishing nets, ropes and plastic bags, occur in the natural environment. It is estimated that $50 \%$ of plastic products, including utensils, plastic bags and packaging, are intended to be disposable (Hopewell et al., 2009; Rochman et al., 2013). Plastic production has continuous growth from
1950 until 2015 (Fig. 1) (PlasticsEurope Market Research Group, 2015).

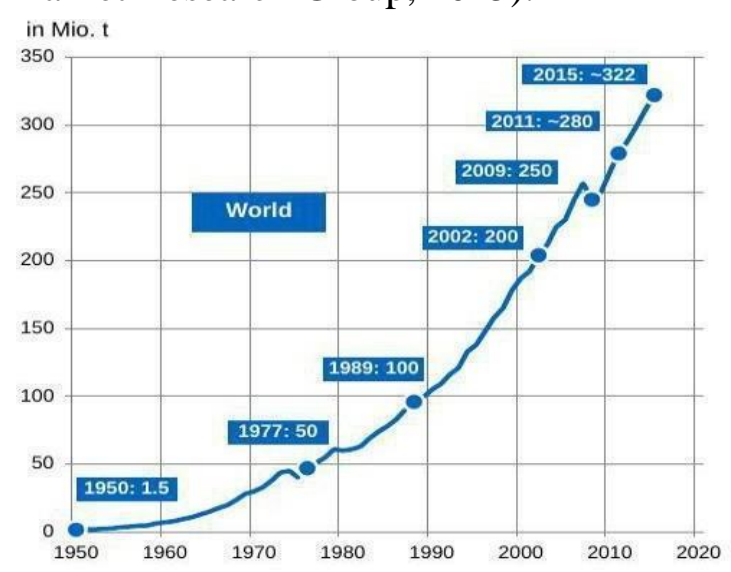

Figure 1. Plastic Production

Plastics has commonly used and abundant polymers are low-density polyethylene (LDPE), polyvinyl chloride (PVC), polystyrene (PS), high-density polyethylene (HDPE), polypropylene (PP) and polyethylene terephthalate (PET) are $90 \%$ total plastic production worldwide (Andrady, 2011). 
Plastic will give negative impact for environment and human health. As some study about plastics, these polymers are also the most commonly found plastics in the environment, especially in marine environment (Tokiwa et al., 2009). Microplastics is smaller plastic with size less than $5 \mathrm{~mm}$, have recently drawn attention because microplastics not only make their way into the marine environment but are also more easily ingested by marine organisms, it's make microplastics may thus act as vectors for the chemical transfer of pollutants within the food chain (Thompson et al., 2009).

Table 1. Occurrence of plastic debris found in water bodies.

\begin{tabular}{|c|c|c|c|c|c|c|c|c|c|}
\hline Location & Regions & $\begin{array}{l}\text { Water } \\
\text { Bodies }\end{array}$ & $\begin{array}{c}\text { Water } \\
\text { Column } \\
\end{array}$ & $\begin{array}{c}\text { Debris } \\
\text { load }\end{array}$ & & $\begin{array}{r}\text { Plastic } \\
\text { Types }\end{array}$ & $\begin{array}{c}\text { Plastic } \\
\text { Sizes }\end{array}$ & $\begin{array}{l}\text { Plastic } \\
(\%)\end{array}$ & Reference \\
\hline$\overline{\mathrm{USA}}$ & $\begin{array}{l}\text { Laurentian } \\
\text { Great } \\
\text { Lakes }\end{array}$ & Lake & $\begin{array}{l}\text { Surface } \\
\text { Water }\end{array}$ & 43000 & ${ }^{1 t e m / k} k_{m}$ & $\begin{array}{l}\text { Macroplastic } \\
\text { and } \\
\text { microplastic }\end{array}$ & $\begin{array}{l}\text { 0.355-0.99990 } \\
\mathrm{mm}(81 \%), \\
1.000-4.749 \\
\mathrm{~mm}(17 \%), \\
\mathrm{N} 4.75 \mathrm{~mm} \\
(2 \%)\end{array}$ & & $\begin{array}{l}\text { (Wilson et } \\
\text { al., 2013) }\end{array}$ \\
\hline \multirow[t]{4}{*}{ Pacific Ocean } & $\begin{array}{l}\text { North } \\
\text { Pacific }\end{array}$ & Marine & $\begin{array}{l}\text { Surface } \\
\text { Water }\end{array}$ & 334271 & \multirow{2}{*}{\multicolumn{2}{|c|}{$\begin{array}{l}\text { item } / \mathrm{km}^{2} \text { Macroplastic } \\
\text { and } \\
\text { microplastic } \\
\text { item } / \mathrm{km}^{2} \begin{array}{l}\text { Macroplastic } \\
\text { and } \\
\text { microplastic }\end{array}\end{array}$}} & $\begin{array}{l}0.355 \text { to } \\
<4.76 \mathrm{~mm}\end{array}$ & $98 \%$ & $\begin{array}{l}\text { (Mallory, } \\
\text { Roberston, } \\
\& \\
\text { Moenting, } \\
2006 \text { ) }\end{array}$ \\
\hline & Australia & Marine & $\begin{array}{l}\text { Surface } \\
\text { water }\end{array}$ & 4256.4 & & & $\begin{array}{l}0.4 \text { to } \\
82.6 \mathrm{~mm}\end{array}$ & $80 \%$ & $\begin{array}{l}\text { (Revelles, } \\
\text { Cardona, } \\
\text { Aguilar, \& } \\
\text { Fernández, } \\
\text { 2007) }\end{array}$ \\
\hline & NE Pacific & Marine & $\begin{array}{l}\text { Surface } \\
\text { water }\end{array}$ & $8-9180$ & Item $/ \mathrm{m}$ & Microplastic & $\begin{array}{l}\mathrm{s} 64.8 \mu \mathrm{m} \text { to } \\
5810 \mu \mathrm{m}\end{array}$ & $75 \%$ & $\begin{array}{l}\text { (Revelles } \\
\text { et al., } \\
\text { 2007) }\end{array}$ \\
\hline & $\begin{array}{l}\text { Geoje } \\
\text { Island }\end{array}$ & Marine & $\begin{array}{l}\text { Surface } \\
\text { water }\end{array}$ & 16000 & Item $/ \mathrm{m}^{-}$ & Microplastic & $\begin{array}{l}\mathrm{sb} 50 \mu \mathrm{m} \text { to } \\
\mathrm{N} 1000 \mu \mathrm{m}\end{array}$ & - & $\begin{array}{l}\text { (Song et } \\
\text { al., 2014) }\end{array}$ \\
\hline $\begin{array}{l}\text { Mediterranea } \\
\text { Sea }\end{array}$ & $\begin{array}{l}\text { n North } \\
\text { pacific } \\
\text { Central } \\
\text { Gyre }\end{array}$ & Marine & $\begin{array}{l}\text { Surface } \\
\text { Water }\end{array}$ & 334.27 & item $/ \mathrm{km}$ & $\begin{array}{l}\text { Macroplastic } 0 \text {. } \\
\text { and } \\
\text { microplastic }\end{array}$ & $\begin{array}{l}355 \text { to } \\
\mathrm{N} 4.76 \mathrm{~mm}\end{array}$ & $98 \%$ & $\begin{array}{l}\text { (Moore, } \\
\text { 2008) }\end{array}$ \\
\hline & Tokyo Bay & Marine & $\begin{array}{l}\text { Surface } \\
\text { water }\end{array}$ & $1.9-3.4$ & $\overline{\text { Items/H }}$ & $\begin{array}{l}\text { aNo } \\
\text { information }\end{array}$ & $\begin{array}{l}\text { No } \\
\text { information }\end{array}$ & $\begin{array}{l}48.3- \\
58.9 \%\end{array}$ & $\begin{array}{l}\text { (Kuriyama } \\
\text { et al, 2011) }\end{array}$ \\
\hline & $\begin{array}{l}\text { Eastern } \\
\text { China }\end{array}$ & Marine & Seafloor & $\begin{array}{l}\text { No } \\
\text { information }\end{array}$ & $\overline{\text { Items } / \mathrm{H}}$ & $\begin{array}{l}\text { aNo } \\
\text { information }\end{array}$ & $\begin{array}{l}\text { No } \\
\text { information }\end{array}$ & $<5 \%$ & $\begin{array}{l}\text { (Lee } \text { et al., } \\
2006)\end{array}$ \\
\hline & $\begin{array}{l}\text { South Sea } \\
\text { of Korea }\end{array}$ & Marine & Seafloor & & Items/H & $\begin{array}{l}\text { aNo } \\
\text { information }\end{array}$ & $\begin{array}{l}\text { No } \\
\text { information }\end{array}$ & $<10 \%$ & $\begin{array}{l}\text { (Lee, Cho, } \\
\text { \& Jeong, } \\
\text { 2006) }\end{array}$ \\
\hline
\end{tabular}

\section{PLASTIC SOURCE}

Plastic debris in marine environment has contributed by land, plastic debris in land has caused by industrial areas, plastic bag usage, plastic bottle, solid waste disposal and human activities around beach and water bodies. Industrial activities, fishing activities will production plastic waste and give an 
impact for marine ecosystem (Fig. 1). $80 \%$ plastic debris in marine environment come from land (Derraik, 2002; Rosarina and Laksanawati, 2018) and 20\% come from commercial fishing. Fishing activities an estimated 640,000 tons of plastic debris are added into the ocean every year, it's totally $10 \%$ of the total marine debris (Good et al., 2010).

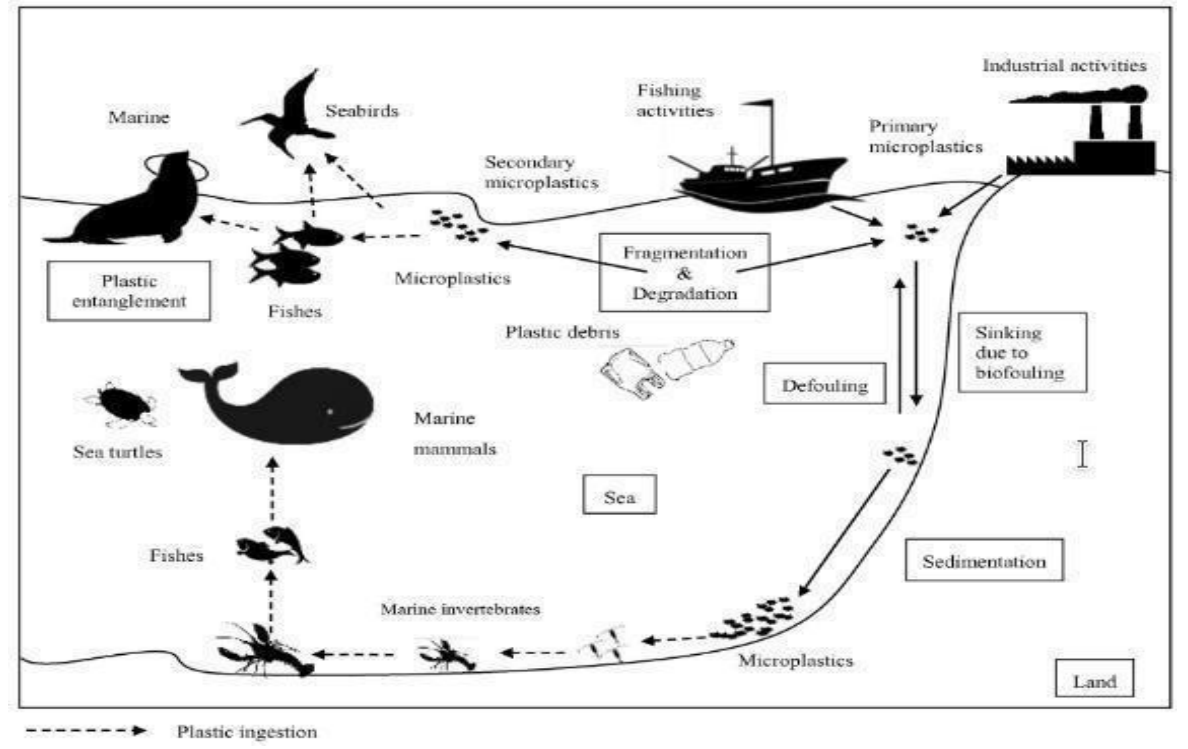

Figure 2. Pathways of plastic debris transportation in marine ecosystem

\section{Effect on Organisms}

Macro and microplastics are hazardous material to organisms (Good et al., 2010). The effects of macroplastics and microplastics include blockage of the intestinal tract, inhibition of gastric enzyme secretion, reduced feeding stimuli, failure to reproduce, decreased steroid hormone levels and delays in ovulation (Azzarello \& Van Vleet, 2007). Microplastic has produced by degradation of plastic caused by ultraviolet (UV) radiation (Fig. 3) and because UV light is absorbed rapidly by water, plastics generally take much longer to degrade at sea than on land (Bergmann, 2009).

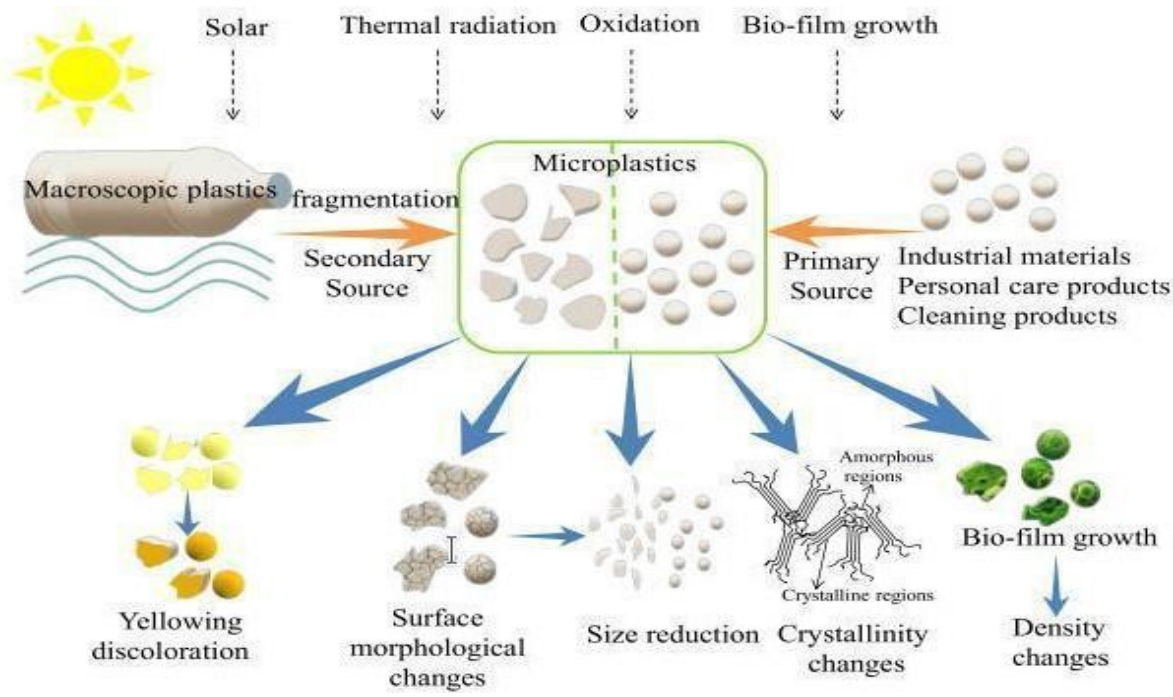

Figure 3. Properties changes of microplastics after degradation by UV 
Microplastics has been a problem for world environment especially on marine environment, majority ocean in the world has been contaminated microplastics (Fig. 4). Microplastic will give physical impact for environment including internal and/or external abrasions and ulcers; and blockages of the digestive tract, which can result in satiation, starvation and physical deterioration. In turn this can lead to reduced reproductive fitness, drowning, diminished predator avoidance, impairment of feeding ability, the potential transfer of damaging toxicants from seawater and ultimately death (Wright et al., 2013;Gregory, 2009). Microplastics ingestion for many organism can see in Table 2.

Table 2. Plastics ingestion in marine organism

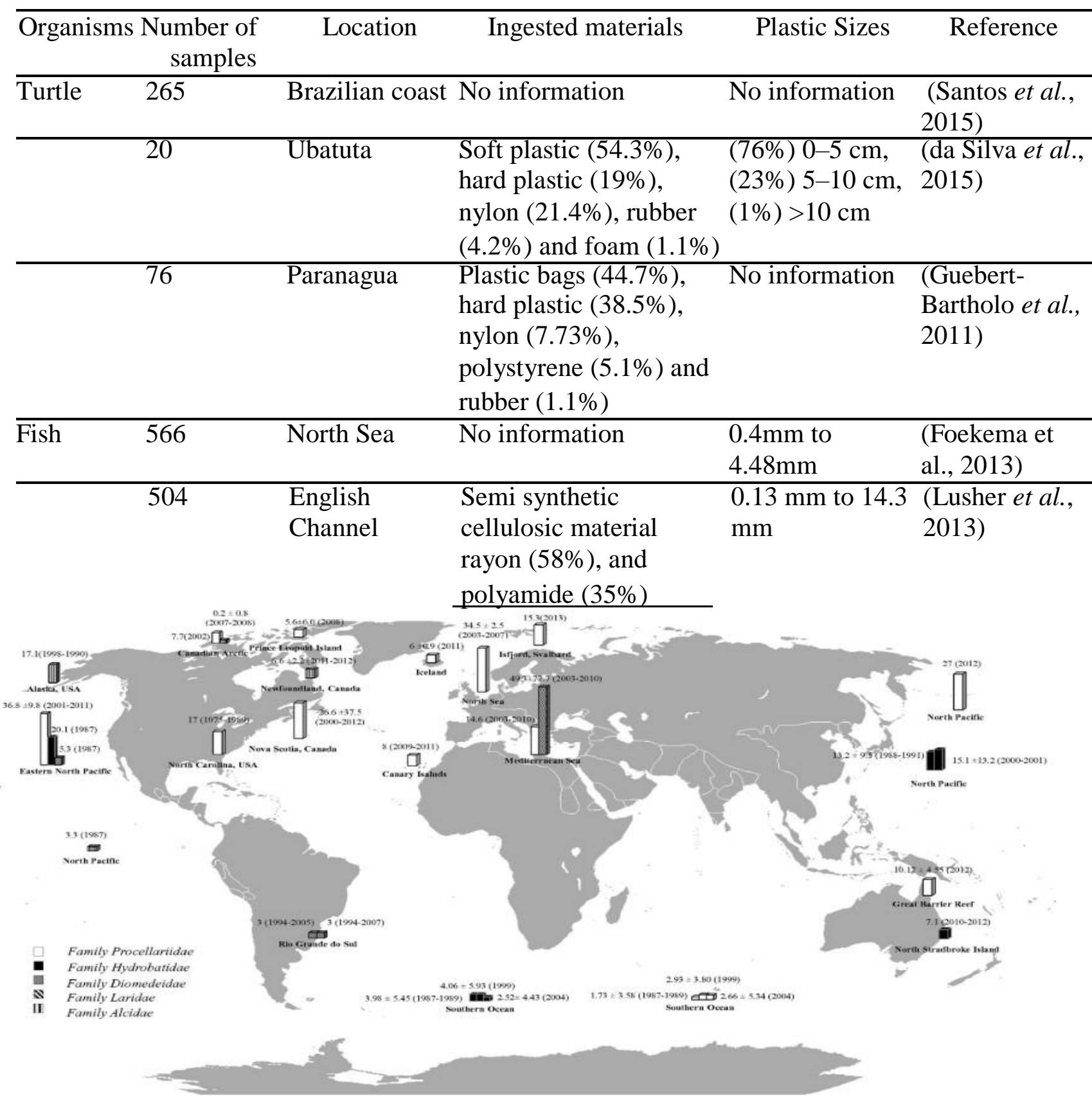

Figure 1. Plastic ingestion found in marine environmental in the world 


\section{CONCLUSION AND FUTURE RESEARCH DIRECTION}

Microplastics are problem for everyone in the world, this problem will give some negative impact for environment and human health. Microplastic has been growing every single years, $80 \%$ plastic debris has come from land and $20 \%$ from fishing activities. Microplastic is degradation material caused by UV and made any problems for marine ecosystem especially biota. Recommendation for future research direction is researcher should make bio-plastic that easy to reduce by nature. This problems need support by all of sector include regulation for limited plastic usage.

\section{REFERENCE}

Andrady, A. L. (2011). Microplastics in the marine environment. Marine Pollution Bulletin, 62(8), 15961605. https://doi.org/10.1016/j.marpolbul.2 011.05.030

Andrady, A. L., \& Neal, M. A. (2009). Applications and societal benefits of plastics. Philosophical Transactions of the Royal Society B: Biological Sciences, 364(1526), 1977-1984. https://doi.org/10.1098/rstb.2008.030 4

Azzarello, M., \& Van Vleet, E. (2007). Marine birds and plastic pollution. Marine Ecology Progress Series, 37, 295-303.

https://doi.org/10.3354/meps037295

Bergmann, M. (2009). Marine Anthropogenic Litter (M. Bergmann, L. Gutow, \& M. Klages, eds.). https://doi.org/10.1007/978-3-31916510-3

da Silva Mendes, S., de Carvalho, R. H., de Faria, A. F., \& de Sousa, B. M. (2015). Marine debris ingestion by Chelonia mydas (Testudines: Cheloniidae) on the Brazilian coast. Marine Pollution Bulletin, 92(1-2), 8-10. https://doi.org/10.1016/j.marpolbu 1.2015.01.010

Derraik, J. G. B. (2002). The pollution of the marine environment by plastic debris: a review

Foekema, E. M., Gruijter, C. De, Mergia, M. T., Franeker, J. A. Van, Murk, A. J., \& Koelmans, A. A. (2013). Foekema EM. Plastic in North Sea Fish. ES\&T 2013. Environmenrtal Science \& Technology, 47, 8818-8824. https://doi.org/10.1021/es400931b

Good, T. P., June, J. A., Etnier, M. A., \& Broadhurst, G. (2010). Derelict fishing nets in Puget Sound and the Northwest Straits: Patterns and threats to marine fauna. Marine Pollution

Bulletin, 60(1), 39-50. https://doi.org/10.1016/j.marpolbu 1.2009.09.005

Gregory, M. R. (2009). Environmental implications of plastic debris in marine settings- entanglement, ingestion, smothering, hangerson, hitch-hiking and alien invasions. Philosophical Transactions of the Royal Society B: Biological Sciences, 364(1526), 2013-2025. https://doi.org/10.1098/rstb.2008. 0265

Guebert-Bartholo, F. M., Barletta, M., Costa, M. F., \& Monteiro-Filho, E. L. A. (2011). Using gut contents to assess foraging patterns of juvenile green turtles Chelonia mydas in the Paranaguá Estuary, Brazil. Endangered Species Research, 13(2), 131143. https://doi.org/10.3354/esr00320

Hopewell, J., Dvorak, R., \& Kosior, E. (2009). Plastics recycling: Challenges and opportunities. Philosophical Transactions of the Royal Society B: Biological Sciences, 364(1526), 2115-2126. https://doi.org/10.1098/rstb.2008. 0311 
Lee, D. I., Cho, H. S., \& Jeong, S. B. (2006). Distribution characteristics of marine litter on the sea bed of the East China Sea and the South Sea of Korea. Estuarine, Coastal and Shelf Science, 70(1-2), 187-194. https://doi.org/10.1016/j.ecss.2006.0 6.003

Lusher, A. L., McHugh, M., \& Thompson, R. C. (2013). Occurrence of microplastics in the gastrointestinal tract of pelagic and demersal fish from the English Channel. Marine Pollution Bulletin, 67(1-2), 94-99. https://doi.org/10.1016/j.marpolbul.2 012.11 .028

Mallory, M. L., Roberston, G. J., \& Moenting, A. (2006). Marine plastic debris in northern fulmars from Davis Strait, Nunavut, Canada. Marine Pollution Bulletin, 52(7), 813-815.

https://doi.org/10.1016/j.marpolbul.2 006.04.005

Moore, C. J. (2008). Synthetic polymers in the marine environment: A rapidly increasing, long-term threat. Environmental Research, 108(2),

131-139.

https://doi.org/10.1016/j.envres.2008 .07 .025

PlasticsEurope Market Reserach Group. (2015). World Plastics Materials Demand 2015 by Types. In Plastics Europe Association of Plastics Manufacturers.

Revelles, M., Cardona, L., Aguilar, A., \& Fernández, G. (2007). The diet of pelagic loggerhead sea turtles (Caretta caretta) off the Balearic archipelago(western Mediterranean): Relevance of long-line baits. Journal of the Marine Biological Association of the United Kingdom, 87(3), 805813.

https://doi.org/10.1017/S0025315407 054707
Rochman, C. M., Browne, M. A., Halpern, B. S., Hentschel, B. T., Hoh, E., Karapanagioti, H. K., ... Thompson, R. C. (2013). Policy: Classify plastic waste as hazardous. Nature, 494(7436), 169-170.

https://doi.org/10.1038/494169a

Rosanti, D. (2016). Stuktur Komunitas Kepiting Uca Pada Zona Avicennia Hutan Mangrove Desa Sungai Batang Kecamatan Air Sugihan Kabupaten Ogan Komering Ilir. Sainmatika: Jurnal Ilmiah Matematika dan Ilmu Pengetahuan Alam, 8(1).

Rosarina, D., \& Laksanawati, E. K. (2018). Studi Kualitas Air Sungai Cisadane Kota Tangerang Ditinjau Dari Parameter Fisika. Jurnal Redoks, 3(2), 38-43

Santos, R. G., Andrades, R., Boldrini, M. A., \& Martins, A. S. (2015). Debris ingestion by juvenile marine turtles: An underestimated problem. Marine Pollution Bulletin, 93(1-2), 37-43.

https://doi.org/10.1016/j.marpolbu 1.2015.02.022

Song, Y. K., Hong, S. H., Jang, M., Kang, J. H., Kwon, O. Y., Han, G. M., \& Shim, W. J. (2014). Large accumulation of micro-sized synthetic polymer particles in the sea surface microlayer. Environmental Science and Technology, 48(16), 9014-9021. https://doi.org/10.1021/es501757s

Thompson, R. C., Hagino, Y., Viet, P. H., Ochi, D., Akkhavong, K., Saquing, J. M., ... Ogata, Y. (2009). Transport and release of chemicals from plastics to the environment and to wildlife Philosophical Transactions of the Royal Society B: Biological Sciences, 364(1526), 2027-2045. https://doi.org/10.1098/rstb.2008. 0284 
Tokiwa, Y., Calabia, B. P., Ugwu, C. U., \& Aiba, S. (2009). Biodegradability of plastics. International Journal of Molecular Sciences, 10(9), 37223742 .

Wibowo, Y., \& Sadikin, A. (2019). Biology in the 21st-Century: Transformation in biology science and education in supporting the sustainable development goals. Jurnal Pendidikan Biologi Indonesia, $5(2)$. doi:https://doi.org/10.22219/jpbi.v5i2.7 956

Wibowo, Y. G., \& Syarifuddin, H. (2018). Rancangan Dimensi Pada Tambang Terbuka Sebagai Upaya Pencegahan Kerusakan Lingkungan Yang Diakibat Oleh Air Asam Tambang. Semnas SINTA FT UNILA, 1, 4953.

Wibowo, Y. G., Zahar, W., Syarifuddin, H., Asyifah, S., \& Ananda, R. (2019). Pengembangan Eco-Geotourism Geopark Merangin Jambi. Indonesian Journal of Environmental Education and Management, 4(1), 23-43.

.02 .031
Wick, A. F., Daniels, W. L., Orndorff, Z. W., \& Alley, M. M. (2013). Lost at Sea: Where is All the Plastic? Soil Use and Management, 29(3), 354-364. https://doi.org/10.1111/sum.12058

Wilson, S., Mason, S., Eriksen, M., Edwards, W., Farley, H., Zellers, A., ... Amato, S. (2013). Microplastic pollution in the surface waters of the Laurentian Great Lakes. Marine Pollution Bulletin, 77(12), 177-

182.

Winarno, H., Muhammad, D., Ashyar, R., \& Wibowo, Y. G. (2019). Pemanfaatan limbah fly ash dan bottom ash dari pltu sumsel-5 sebagai bahan utama pembuatan paving block. Jurnal Teknika, 11(1).

Wright, S. L., Thompson, R. C., \& Galloway, T. S. (2013). The physical impacts of microplastics on marine organisms: A review. Environmental Pollution, 178, 483-492. https://doi.org/10.1016/j.envpol.2013 